\title{
Felix Wemheuer, Famine Politics in Maoist China and
} the Soviet Union,

New Haven, Yale University Press, 2014, XIX-325 pp.

\section{Lucien Bianco}

Translator. Will Thornely

\section{(2) OpenEdition}

\section{Journals}

\section{Electronic version}

URL: http://journals.openedition.org/chinaperspectives/6733

DOI: 10.4000/chinaperspectives.6733

ISSN: 1996-4617

\section{Publisher}

Centre d'étude français sur la Chine contemporaine

\section{Printed version}

Date of publication: 1 June 2015

Number of pages: 60-61

ISSN: 2070-3449

\section{Electronic reference}

Lucien Bianco, «Felix Wemheuer, Famine Politics in Maoist China and the Soviet Union, », China Perspectives [Online], 2015/2 | 2015, Online since 01 January 2017, connection on 22 September 2020 URL : http://journals.openedition.org/chinaperspectives/6733; DOI : https://doi.org/10.4000/ chinaperspectives.6733 


\section{Book reviews}

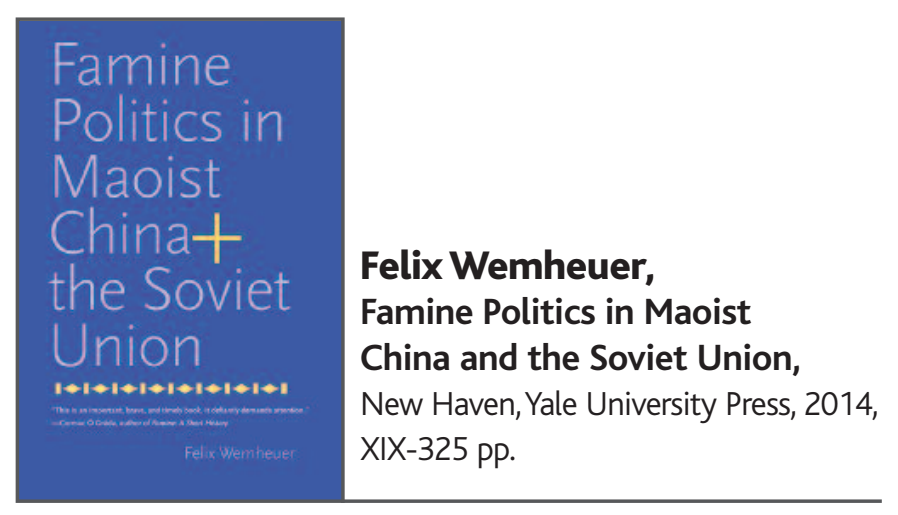

\section{LUCIEN BIANCO}

A fter seeing the extent to which the famine remained one of the most terrible periods in the lives of peasants he interviewed in the Henan Province, a young German sinologist (born in 1977) carried out over a decade of research into the Great Leap Forward. This resulted in a number of works focusing on the famine, (1) including the present comparison between the famine of 1959-1962 and that which hit the USSR. Such a comparison is relevant not only because of the similarities between the two revolutionary regimes, but also because more than $80 \%$ of the world's famine victims in the twentieth century died in these two countries.

The structure is not the most satisfactory aspect of this good book. Excluding the third part (Chapters 5 to 7), which is dedicated to Ukraine and Tibet, the comparison between the Soviet and Chinese famines is covered essentially in the first part (Chapters 1 and 2). The second part, which covers only China, takes up and develops the themes introduced in the first part: Chapter 3 refers to Chapter 1 (conflicting reports between the state and peasants before the famine) and Chapter 4 refers to Chapter 2 (the way in which the famine was managed sacrificed the countryside in order to protect the cities). An epilogue details the lessons drawn from these catastrophes by the two regimes, which have not experienced further famines since 1962 in China's case and 1947 in the USSR. A substantial conclusion summarises the main contributions of the book, in a similar way to how the last page (or a little more) of each chapter sums up the themes developed in that chapter. The reader pressed for time might therefore be tempted to limit himself to these mini-conclusions and the general conclusion.

In doing so, he would miss out on the objective intellectual reflection pursued throughout the book on what is a burning issue. While clearly demonstrating the main responsibility of the two regimes in causing the disasters, the author also underlines the enormous burden inherited by both agrarian empires. Russia, too, had been a "land of famine." (2) A peasant born in south Russia in 1890 and living until 1950 would have lived through the famines of 1891, 1921-1922, 1932-1933, and 1946-1947, the latter following a famine fomented by the Nazis during the Second World War. A Chinese peasant born in 1900 in Henan and dying at the beginning of the Cultural Revolution would similarly have experienced the famines of 1931, 1943, and 1959-1962 (pp. 32-33). The author could also have included the famine of 1920-1921, which struck the northern part of the province. Even during famine-free years, hunger was never far away and killed thousands of people, for example in 1950, 1951,1955, and 1956, while tens or even hundreds of thousands of peasants fled regions hit by the "spring shortages" (chunhuang) every year (p. 86). The situation was therefore very strained throughout the first decade of the regime, and was nearly as tense in the Soviet Union during the civil war and the 1920s. This was the very difficult legacy that the two regimes managed, as best they could, before embarking (in 1929 and 1958) on modernisation drives that were excessively ambitious, impatient, and radical, and gave rise to famine. In terms of the periods prior to 1929 and 1958, Chapters 1 and 3 are indispensable when it comes to understanding the famine, which was brewing before it broke out: the "contribution" demanded from the peasantry in order to finance industrialisation set the scene for the crisis, and the politicisation of hunger (saying that there was a lack of grain was proof of ideological deviance) prevented the victims from complaining when the famine was at its height.

In terms of the food crisis itself, the mechanisms that made agricultural production fail have been exposed amply in many works. ${ }^{(3)}$ Wemheuer rightly draws attention to relations between the cities and countryside. The swift growth of the industrial workforce and the rapid influx of country folk into the cities suddenly made the provision of food to citizens holding an "iron rice bowl" much more delicate. As food shortages worsened, both Stalin and Mao gave absolute priority to this group, for food riots had to be avoided in the cities, where the regime felt vulnerable and wished to maintain stability. In the USSR, the cities were even split into three categories: Moscow, Leningrad, Kharkov, Dnepropetrovsk, and a handful of other industrial cities had access to the grain harvested on a national level; 80 others cities were supplied in part by the central stores, but had to turn to their surrounding areas to make up gaps in their supplies; the remaining cities and towns had to rely solely on local harvests (p. 63). In order to protect themselves, the two regimes exacerbated the rural famine by requisitioning excessive quantities from the producers so as to reduce urban rationing as much as possible. Similarly, Wemheuer reasons and demonstrates that the Chinese famine was finally overcome less by concessions that were granted

1. Among others, Felix Wemheuer, Steinnudeln: Ländliche Erinnerungen und staatliche Vergangenheitsbewältigung der « Grossen Sprung » Hungersnot in der chinesischen Provinz Henan (Stone Noodles: Rural and official memories of the Great Leap famine in China's Henan Province), Frankfurt, Peter Lang, 2007; Kimberley Ens Manning and Felix Wemheuer (eds), Eating Bitterness: New perspectives on China's Great Leap Forward and famine, Vancouver, University of British Columbia Press, 2011. This book was the subject of a review essay in China Perspectives, No. 2013/3, pp. $85-90$

2. Walter Mallory, China: Land of Famine, New York, American Geographical Society, 1926.

3. Apart from Manning and Wemheuer, and in addition to many other studies: Frank Dikötter, Mao's Great Famine: The history of China's most devastating catastrophe, 1958-62, London, Bloomsbury, 2010, reviewed in China Perspectives, No. 2011/2, pp. 74-75, and above all Yang Jisheng, Mubei: Zhongguo liushiniandai dajihuang ji shi, Hong Kong, Cosmos Books, 2008, 2 Vol. (English translation by Stacy Mosher and Guo Jian, Tombstone: The Great Chinese Famine, 1958-1961, New York, Macmillan, 2012). This book has been the subject of review essays in China Perspectives, No. 2009/1, pp. 98-101, for the Chinese version and No. 2013/3, pp. 88-90, for the French version. For the USSR, a good starting point is R.W. Davies and Stephen Wheatcroft, The Years of Hunger: Soviet agriculture, 1931-1933, NY, Palgrave Macmillan, 2004. 
- too late - to the producers (private plots of land restored, the unit of accounting delegated down to the work team level, the contract responsibility system, etc.) than by the decision - which also came too late - to send 20 million recently-arrived city dwellers back to the countryside and import grain from capitalist countries such as Australia and Canada. These imports helped provide food for the city dwellers, who were now fewer in number, in turn making it possible to reduce the collections demanded from producers. The latter were nevertheless left with the task of feeding those returning from the cities, in waves staggered over several years. This departing manpower was missed less acutely in industry because the end of agricultural exports and the import of grain meant it was no longer possible to import machine tools: industry was condemned to mark time even before the leaders had reversed the priorities by placing "agriculture at the forefront." A birth control campaign was also started in 1962, and - until a major turnaround in 1978 - the rural exodus was restricted, as a result of which the level of urbanisation increased only minimally, from $17.3 \%$ in 1962 to $17.92 \%$ in 1978 (p. 230). The lessons to be learned from the disaster are analysed in the epilogue, but to my eyes, Chapter 4 ("Preventing Urban Famine by Starving the Countryside, 1959-1962") represents the best section of the book.

On the other hand, Chapters 5 to 7, which make up the third section ("Famines on the Periphery"), are less important and, in my opinion, too long. They compare Ukraine, which was struck harder than any other region of the USSR by the famine of 1932-1933 (Kazakhstan was proportionally hit harder still in 1931), and Tibet, where the losses were less serious than those in Anhui, Henan, and many other provinces populated almost exclusively by the Han. These three chapters deal less with the famine itself than with the contradictory accounts concocted by the official historiography and the Ukrainian or Tibetan nationalists. Interest therefore shifts to questions concerning the autonomy, separatism, or secession of outlying regions occupied by national minorities, a subject that is no doubt interesting in itself, (4) but that diverts us from the essential subject and contributions of the book.

The final shortcoming of the book relates to its few instances of inaccuracy or inconsistency. China's population in 1964 loses 13 million people between page 229 (704 million) and the following page (691 million), which is an excusable error, corresponding roughly to the natural annual growth at the time. Table 4.3 (Average annual consumption of grain per inhabitant in the cities and countryside, China 1952-1966) and the text on page 133 raise a more serious problem: $362 \mathrm{jin}$ is probably a typographical error that should read 312 jin, but on the next line, an incorrect calculation matches up 386 jin annually with 493 grams per day (instead of 529). Incidentally, the incorrect calculation is possibly closer to reality than the 386 jin taken from Table 4.3, which indicates, probably incorrectly, that urban consumption was higher in 1960 than in 1958.

These are trivialities compared to the gems unearthed elsewhere, starting with two evocative graphs on pp. 88 and 245. That on p. 88 illustrates the operation of the unified grain purchase and sale system that was in force from 1953 to 1960; that on p. 245 shows the hierarchy of grain consumers, placing at the bottom the producers of rice and wheat consumed by the upper levels. In addition to these examples, in no particular order, are Kropotkin's warning (past revolutions failed because they were unable to feed the population during times of radical change, p. 46), the comparison between the Soviet internal passport and the hukou (p. 65), and the millions of deaths that could have been avoided by an earlier end to grain exports (in the USSR, all of the deaths resulting from hunger, p. 247). Furthermore, solidly reasoned theoretical discussions introduce or provide the crowning achievements of the empirical research. To cite but a few examples here, the author refutes the theories amplifying the peasant resistance and its impact (pp. 78-82, 149, and 152), and offers a critical examination of the theories of Armartya Sen and Jean Drèze. Sen's famous "entitlement approach" (the distribution of commodities and the denial of rights were more significant factors in the famine than the reduction or lack of availability of food) is ultimately shown to have its limitations, without being entirely disproven (pp. 149-152 and 246). The theories of Drèze and Sen as to how democracy is more capable of preventing famines than authoritarian regimes succumb much more quickly to the author's reasoning (pp. 237239). His arguments are as convincing as they are learned, the Soviet case following the Chinese case before itself being encapsulated by other examples (India and Africa) and other centuries (Imperial China and its system of organising assistance).

\section{Translated by Will Thornely.}

I Lucien Bianco is professor emeritus at EHESS (School for Advanced Studies in Social Sciences), Paris (biancosud@gmail.com).

4. As far as the USSR is concerned, the standard reference is Terry Martin, The Affirmative Action Empire: Nations and nationalism in the Soviet Union, 1923-1939, Ithaca, London, Cornell University Press, 2001.



\section{ROGIER CREEMERS}

$\mathrm{H}$ ow does one begin to understand Chinese law? How does one do justice to the complexity of the legal (re)construction process that has taken place since the late 1970s? Observers must navigate between the Scylla of teleological approaches that too easily assume trajectories towards ill-defined notions of rule of law and democratisation, and the Charybdis of historical determinism. They must do justice both to a continuing dominant view of law as an instrument of state power and the agency of lawyers, judges, academics, and activists inside and outside of the legal system who seek to develop and apply their own conceptions of professionalism and justice. They must explore the influences of socialism and foreign legal transplants, and the impact of autochthonous traditions and concepts. They must cater to the preconceptions of legal scholars, for whom the relative immaturity of China's legal system is sometimes difficult to conceive, and those of China experts, who are often predisposed to seeing law as merely a continuation of politics and power and lacking autonomous existence. 